\title{
Forage Quality on the Arizona Strip
}

\author{
Art Meen
}

$\mathrm{A}$ cow's nutritional needs change with time according to her physical state. Poor forage quality can have a significant impact on calf health and vigor, on calf weaning weights, and on mother cow reproductive performance-both calf crop percent and when the calves are born. All of these things hit the rancher directly in the pocketbook. Information on a cow's nutritional needs has been available for years. But there has been very little information on the major forages available to cattle on the northern Arizona-southern Utah portion of the Colorado Plateau. Samples of major forages were collected monthly over a 3-year period and analyzed for crude protein content $(\mathrm{CP})$, energy content (TDN), and phosphorus (P). During the last year of the study some samples were also analyzed for several important micro-nutrients. It is not possible to display all the data here. Examples from a higher elevation collection site will be used as illustration and our findings will be discussed in general. A complete list of ecological sites and species collected can be found in Table 1 .

The information gathered during this study will be used to discuss the following points:

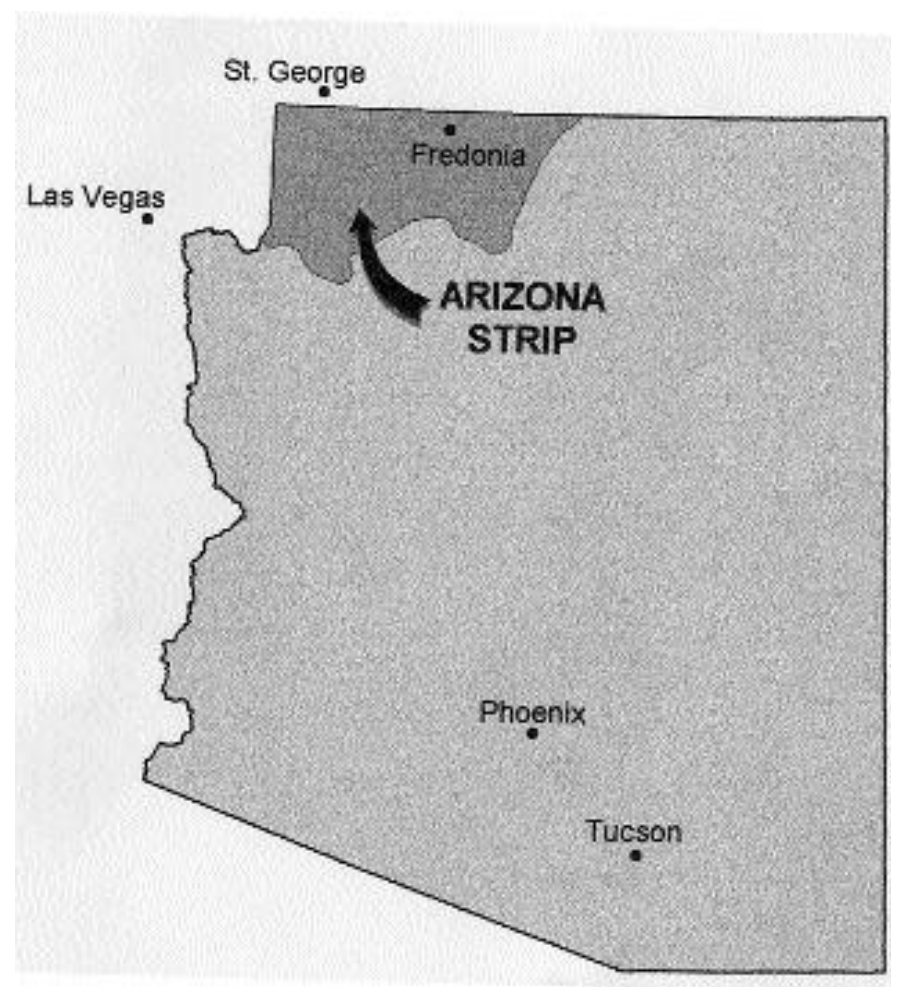

1) The general pattern of nutritional quality through the different seasons

2) Any differences between years, and how these differences can be tied to rainfall

3) How cool-season grasses compare to warm-season grasses, and how grasses compare to browse

4) Whether or not there are differences in forage quality between low and high elevations

\section{Protein $(\mathbf{C P})$}

Generally speaking, crude protein content needs to be around $7 \%$ to satisfy the needs of rumen microbes. Below this threshold, especially as it gets down close to $6 \%$ or lower, forage intake begins to drop sharply. Forage digestibility will also be reduced. Our study data strongly suggests that crude protein should be regarded as the nutrient most likely to be deficient. There are two seasons when forage CP content drops below required levels - the dormant season during the winter months and the "summer slump" period. Of the two, the summer slump period is the most variable from year to year. At higher elevations around 5,000 feet, over the three years of this study, the winter dormant season consistently covered all of December, January, February, and at least the first half of March. Two of the three years studied had poor late summer and fall moisture. Crude protein contents of three forage species from the same site near 5,000 feet are representative of the typical pattern observed (Figure 1). Included is the "typical" nutrient requirements of a mature

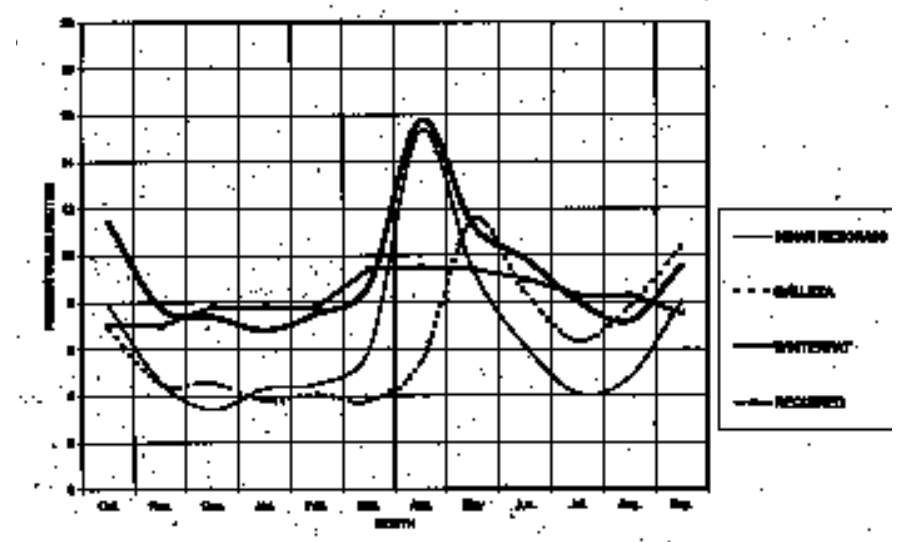

Fig 1. Protein content of key species on Gypsum Upland (average of three years). 
Table 1

LAND RESOURCE UNITS (LRU's), ECOLOGICAL SITES, AND SPECIES SAMPLED

SITE

SPECIES

ELEVATION

\begin{tabular}{|c|c|c|}
\hline Sandy Upland & $\begin{array}{l}\text { D30-2 MOHAVE DESERT SCRUB } \\
\text { PRECIPITATION 6-9” PER YEAR } \\
\text { white bursage } \\
\text { Nevada Mormon tea } \\
\text { winterfat } \\
\text { white ratany } \\
\text { big galleta } \\
\text { Indian ricegrass } \\
\text { sand dropseed } \\
\text { desert globemallow }\end{array}$ & 2105 feet \\
\hline Cobbly Limy Upland (Deep) & bush muhly & 2605 feet \\
\hline Sandy Wash & wooly-fruited bursage & 3020 feet \\
\hline Gypsum Upland & $\begin{array}{l}\text { D35-4 COLORADO PLATEAU COLD DESERT GRASSLAND } \\
\text { PRECIPITATION 7-11” PER YEAR } \\
\text { winterfat } \\
\text { galleta } \\
\text { gyp dropseed }\end{array}$ & 4715 feet \\
\hline Sandy Loam Upland (Calcareous) & $\begin{array}{l}\text { fourwing saltbush } \\
\text { Nevada Mormon tea } \\
\text { winterfat } \\
\text { galleta } \\
\text { Indian ricegrass } \\
\text { needle and thread } \\
\text { sand dropseed } \\
\text { black grama }\end{array}$ & 4930 feet \\
\hline Shallow Loamy & $\begin{array}{l}\text { D35-3 COLORADO PLATEAU SAGEBRUSH-GRASSLAND } \\
\text { PRECIPITATION 10-14" PER YEAR } \\
\text { Nevada Mormon tea } \\
\text { blue grama } \\
\text { galleta } \\
\text { Indian ricegrass } \\
\text { needle and thread } \\
\text { bottlebrush squirreltail }\end{array}$ & 5150 feet \\
\hline
\end{tabular}

\begin{tabular}{|c|c|c|}
\hline Limestone Slopes & $\begin{array}{l}\text { D39-3 GRAND CANYON WOODLAND-SHRUB } \\
\text { PRECIPITATION 13-17" PER YEAR } \\
\text { cliffrose } \\
\text { blue grama } \\
\text { muttongrass } \\
\text { bottlebrush squirreltail }\end{array}$ & 6440 feet \\
\hline
\end{tabular}

cow of average size which calves in March. The requirement line assumes no net weight loss or gain by the cow, except for the fetus.

High Desert - The cool-season grasses Indian ricegrass, needle-and-thread, and muttongrass all begin a rapid increase of crude protein content around the middle of March; CP peaks in April and early May and has dropped below the requirement line again by June. Bottlebrush squirreltail follows a similiar pattern except that CP content begins to climb earlier and is generally above the requirement line by the middle of March, making it a very valuable early spring forage. All cool-season grasses sampled had poor CP content through the months of June, July, and August. Precipitation in June and July had little effect on these grasses but good moisture in the late August-early September period provided a response, especially in needle-and-thread and muttongrass. Precipitation was below average in the winter and spring of 1996; peak CP content 


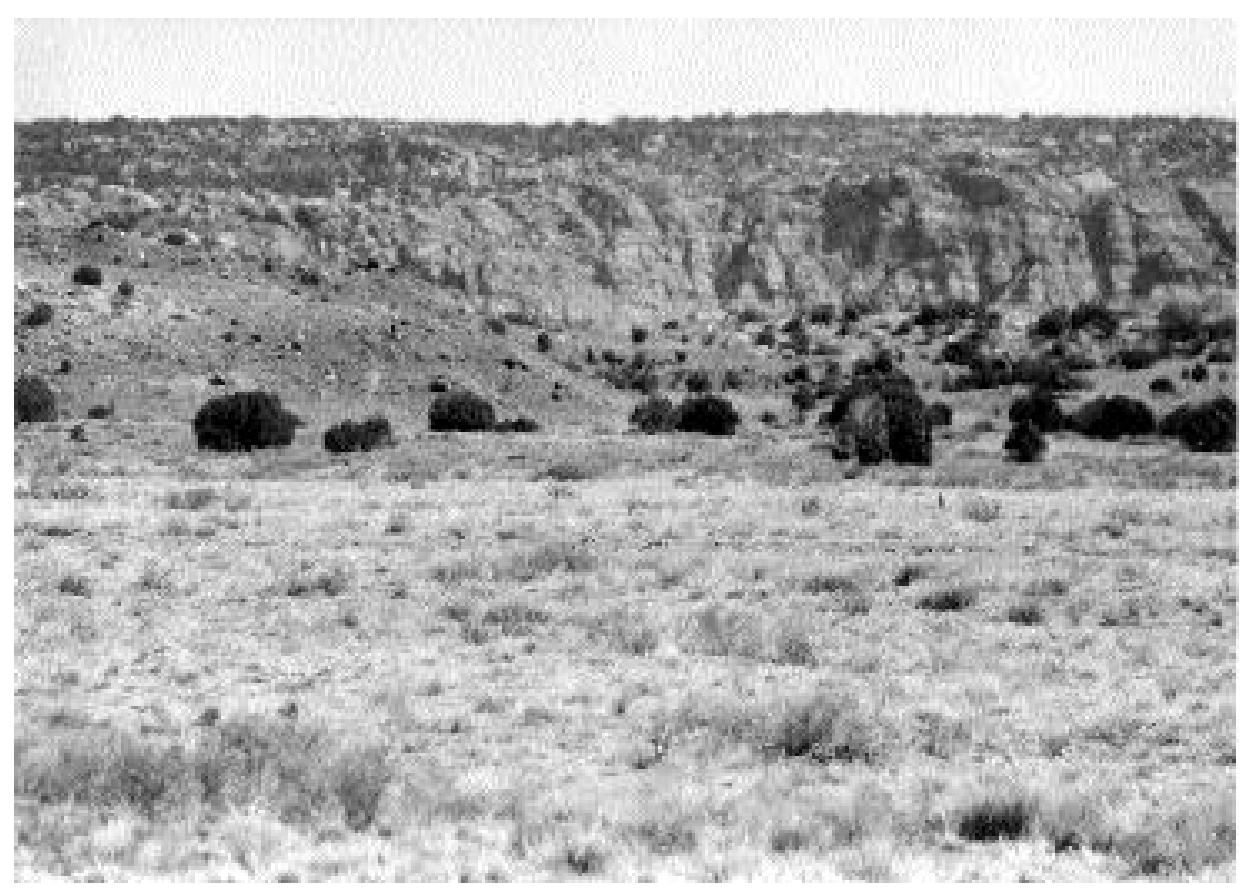

Sandy Loam Upland site.

of the cool-season grasses was lower in this year, and did not last as long as in 1997 and in 1998. CP content during the dormant periods was the same in all years.

All the samples of warm-season forage grasses that we collected (galleta, sand dropseed, blue grama and black grama) show a similar pattern. All species responded to spring moisture and warmer temperatures with an increase in CP which began in April and peaked in May. Both galleta and sand dropseed show a marked increase during May and often the CP content was well above the requirement line, while blue grama and black grama $\mathrm{CP}$ rose much less in the spring-in most samples CP did not reach the requirement line. Crude protein content in warm-season grasses during the summer is very dependent on moisture. It responds quickly to rain, and can drop back down just as quickly if the rains do not continue. It seems that there are species differences. All the grasses had good CP content with summer growth, but blue grama was much higher than galleta, while sand dropseed fell between them. Black grama $\mathrm{CP}$ appears to be similiar to galleta during the summer. During the winter dormancy, however, black grama appears to be a little higher than the other three warmseason grasses. We only had one sam- ple each month for black grama, but our observation is consistent with other desert areas in Arizona where black grama is a more common grass and is often merely semi-dormant during the winter.

Perhaps the most important observation on the browse species we sampled during this study is that during the dormant period each shrub species sampled had considerably higher $\mathrm{CP}$ content than any of the grasses. In fact, many of the samples taken from December through March each year had protein levels at or above the requirement line. Shrub CP levels were also high compared to grasses during the "summer slump" period. While it is beyond the scope of this summary to discuss how the tannins and phenolic compounds present in shrubs impact their actual digestibility, it is fair to say that available CP content is probably somewhat lower than our numbers suggest. However, this does not lessen the importance of these browse species to the rancher-they can represent a great deal of money in saved supplementation costs. Two browse species collected on the upper desert-fourwing saltbush and winterfatshow a spring peak of CP content in April or May, between the cool-season and warm-season grasses, followed by a drop in protein in June and July. Like warm-season grasses,

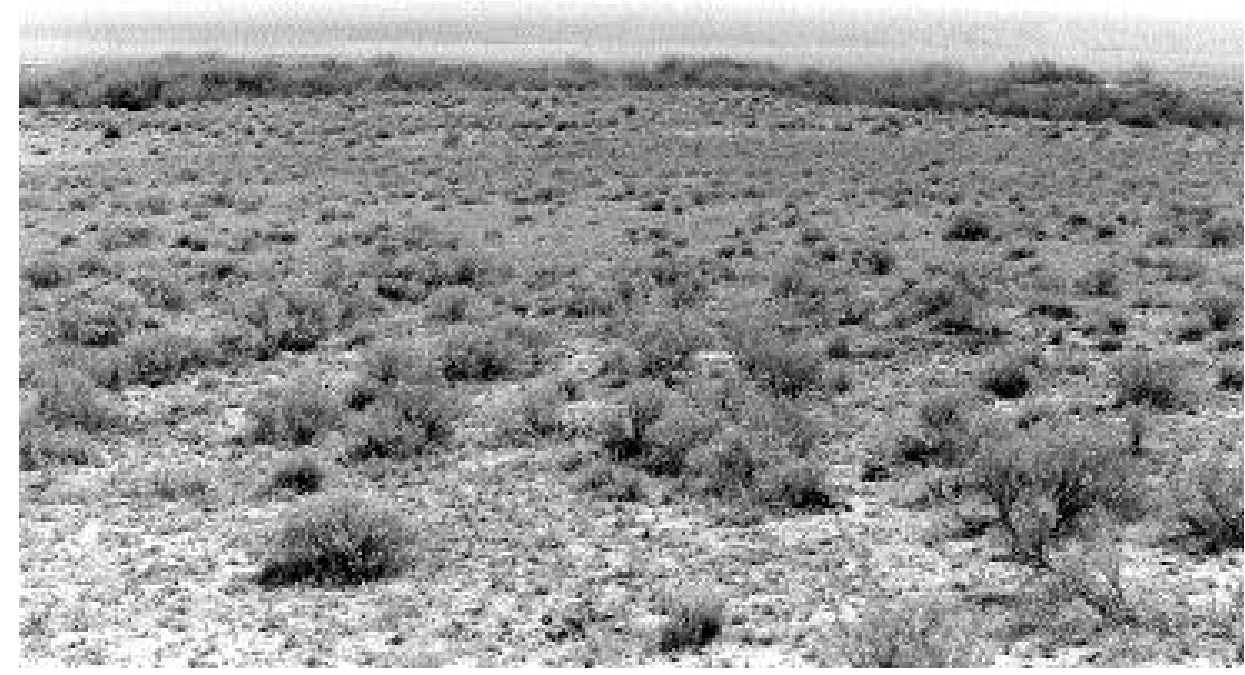

Gypsum Upland site used for graphs. 
a protein increase in shrubs during the summer depends at least in part on the summer rain. Summer CP is also likely influenced by the stage in their growth and fruiting cycle. Mormon tea appears to have a slightly different pattern of protein content. Our data shows a peak in May and June, about a month later than saltbush and winterfat, and tea seems to hold a higher level of CP over the summer slump period of hot weather and little rain. Our sampling also indicates a rise in Mormon tea protein levels in late winter (February). Cliffrose shows less variation in CP content than the other browse species. Except for two samples collected during the second year, all other cliffrose samples indicate a protein content between 7 and 11 percent. Like the grasses, CP content of the shrubs is consistently lower in a spring of poor moisture than it is in years of average moisture or better. The tentative conclusion is that there is no real difference in $\mathrm{CP}$ content of shrubs in these two years of average or better moisture. It should be noted that none of the three spring growth seasons we sampled could be considered outstanding. Samples collected during a truly wet year might show us a different pattern.

Comparing our results to amount of moisture received and the timing of that moisture brings up two important points. For the spring growing season, a wet winter does not compensate too well for a dry March and April (especially March); on the other hand, good spring moisture (especially in late February and March) goes a long way to making up for poor winter moisture. Our data also suggests that good late summer-early fall growth of forage increases the protein quality the following spring, even if available moisture that spring is merely average.

Low Desert-At an elevation of around 2,000 feet, coolseason grasses have a peak CP content in late February and early March, about two months earlier than the high desert samples. We collected fewer samples from this elevation, but those we did collect exhibited the same characteristics as those from higher up. Protein content of big galleta and sand dropseed peaks in April instead of May at 2,000 feet. Also, the protein in this spring growth does not appear to be as high, barely reaching the requirement line or falling short of it. This may be due to moisture received. Records from Mesquite, Nevada (12 miles from our sampling site) show that rainfall for spring growth during the first year of our study (Oct. 1995-March 1996) was only $40 \%$ of the average, while in our second year it was about $75 \%$ of the average. In both of these years the $\mathrm{CP}$ content of big galleta and sand dropseed was well below the requirement line, although the second year was significantly higher than the first. In our final year of sampling moisture received was $125 \%$ of average, however, and the CP levels of these two grasses barely reached the requirement line. This suggests that warm-season grasses on the low desert have a lesser crude protein content than warm-season grasses at higher elevations. The shrubs we sampled (white bursage, Mormon tea, winterfat, white ratany, and wooly-fruit bursage) also appear to contain a lower protein content than the shrubs higher up. Crude protein levels during the sec- ond year were very similiar to those of the first year, and appear to be strongly influenced by the almost complete lack of growth during the first year of sampling. Data from the third year showed consistently and significantly higher CP levels, probably because there was at least some growth during the second year. Although not conclusive, our study indicates that the lower desert browse species contain a slightly lower CP content when dormant than the species at the higher elevations.

\section{Energy (TDN)}

All animal functions and biochemical processes require a source of energy; quantitatively, energy is the most important part of an animal's diet. Animals can obtain energy from most organic compounds such as carbohydrates, fats, fiber, and excess protein. Forage contains up to $70 \%$ or more of carbohydrates. The level of TDN in forage, like protein, has a direct effect on the rate of digestion in the rumen and therefore on feed intake. Forage with lower digestibility requires more time in the rumen, and intake is limited by available space. The TDN requirements for a cow are at their highest during peak milking and late pregnancy, and are much lower when a cow is dry or in the early stage of pregnancy. Our study shows that forage TDN levels are inadequate during part of the year. However, energy does not appear to be as limiting as protein during much of the dormant period, and TDN levels may be adequate during most summers regardless of the summer slump. The graph in Figure 2 is of the same species and site as those for protein, so that direct comparison can be made; they are representative of the typical pattern observed.

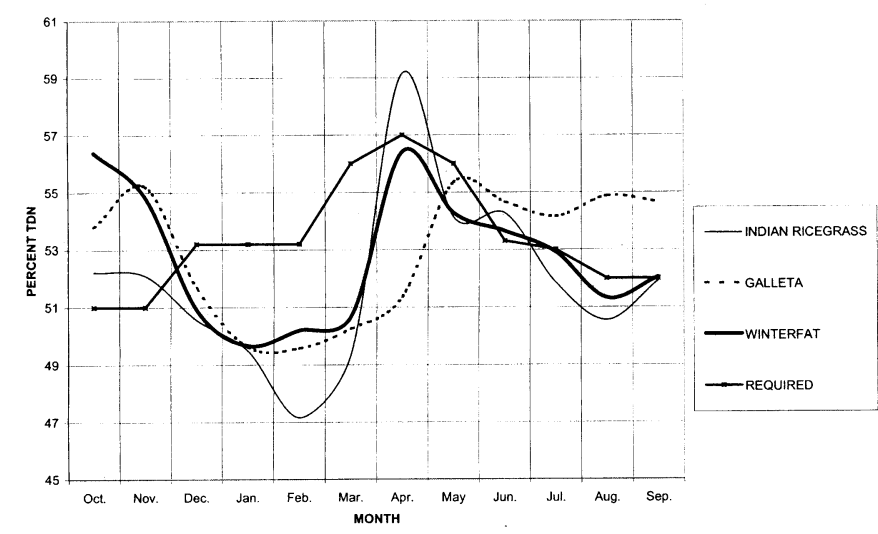

Fig. 2. TDN content of key species on Gypsum Upland (average of three years).

High Desert-At these elevations the TDN content of cool-season grasses shows the same April peak as protein. However, peak TDN content of a species is quite similiar each year; unlike protein, there is no apparent correlation between TDN content and the amount of spring moisture. While cool-season grasses show a drop in TDN over the 
summer, the level remains right around the requirement line. Also, TDN levels do not peak very high - while energy content appears to be adequate for nutrition levels in the spring, there is not a large surplus. Finally, although TDN levels appear to be adequate in the late fall and early winter, the energy content of most of our cool-season samples consistently trended down over the winter while protein levels appear to remain relatively stable through the dormant months.

Warm-season grasses at higher elevations show an energy increase beginning in April and peaking in May, followed by a slight decline. The TDN levels will rise again according to growth from summer moisture. As with protein, galleta and sand dropseed seem to have higher spring levels of energy than the gramas, while blue grama tends to retain a higher level during the summer months. Most samples of all species had TDN levels above the requirement line during the summer, regardless of fluctuations. Black grama appears to have a higher energy content later into the fall and winter than the other warm-season grasses. Energy content of most species trended down throughout the winter and reached their lowest point in February and March.

Given the amount of woody material present in browse, TDN contents of the species we sampled were surprisingly high. The samples of both fourwing saltbush and cliffrose were consistently higher than all grasses during the dormant period, and as high as warm-season grasses during the summer - these two shrubs showed less variation in TDN than other shrub species. Winterfat and Mormon tea also seem to retain a TDN level at least as high as grasses when dormant, and fall somewhere between warm- and cool-season species during the growing season.

Low Desert-Our sampling from 2,000 feet elevation indicates that TDN content of cool-season grasses has the same patterns as we found higher up, with the peak coming in March instead of April. One difference noted is that TDN content does not appear as likely to meet requirements during the summer. Perhaps this is because of more complete dormancy of cool-season grasses in that hotter, drier environment. The TDN levels of both big galleta and sand dropseed appear to be lower during the entire growing season, staying well below the requirement line most of the time. Big galleta is a very coarse grass with more poorly digested lignin and fibrous material, but some of the sand dropseed samples appeared to be quite succulent; like the observations for protein, energy content of the warm-season grasses appears to be less on the low desert than on the higher plateau. The TDN levels in low-desert shrubs also compare favorably with grass samples, but like the grasses appear to be lower in energy than shrub species at higher elevations.

\section{Phosphorus (P)}

Our study indicates that phosphorus levels in the forage are deficient for much of the year. These levels fluctuate closely with active growth and protein levels. On the upper desert P levels peak in April in cool-season grasses, while

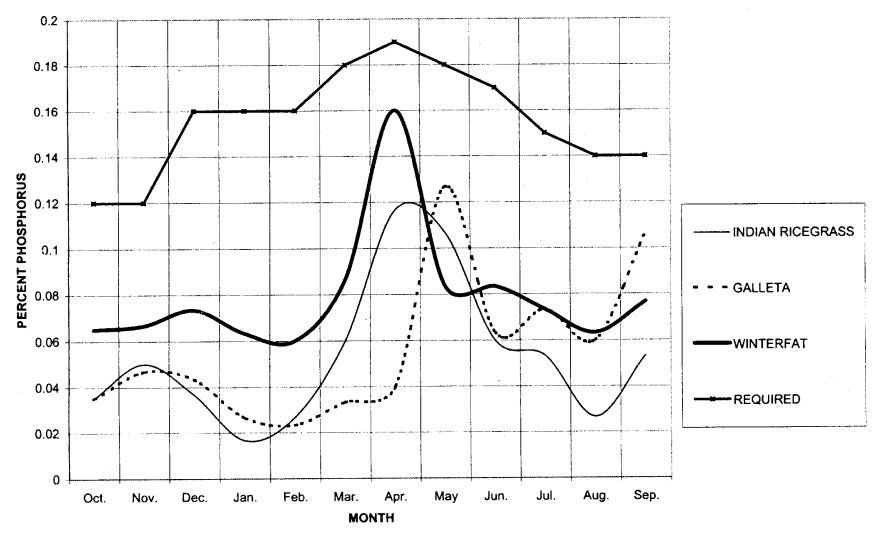

Fig. 3. Phosphorus content of key species on gypsum upland. (Average of three years).

warm-season grasses peak in May and rise again with summer growth. Browse species exhibit a similiar pattern. The shrubs appear to contain more $\mathrm{P}$ during periods of slow growth or dormancy than the grasses do. Figure 3 is a graph of $\mathrm{P}$ levels of the three species and site shown previously. There was a significant difference in peak P levels among the three years of this study. Most of our samples showed that levels in the third year (spring 1998) were quite a bit higher at their peak, while the growing season of the second year (1997) was substantially lower. Levels of the first year (1996) were somewhere in between. Research on cropland has shown that both cool soil temperatures and drought conditions will reduce the availability of soil phosphorus to plants. Unfortunately our study does not have temperature data available. However, it is our conclusion that poor growth during a prior year (for example 1996) has a significant effect on forage $\mathrm{P}$ levels the following year. A cool and wet early spring may also result in lower levels of forage phosphorus.

It should be noted that there is less agreement among researchers about actual $P$ requirements for livestock than there is for protein and energy. Also, the capacity of the skeleton to provide $\mathrm{P}$ during periods of deficiency means that effects of a dietary shortage are not as immediate. However, the data from this study clearly indicates that phosphorus levels in forage may be quite deficient for extended periods of time. Some samples showed levels above the requirement line during times of active forage growth, especially in 1998-all the species we sampled had P levels well below the requirement line for at least several months during each year, and sometimes for the entire year. Browse species tended to have higher $P$ levels when dormant than any of the grasses. There was no apparent difference among the cool-season and warm-season grasses.

\section{Other Minerals}

During the final year of this study, selected samples were analyzed for five micro-nutrients considered most likely to be deficient in this area-selenium, molybdenum, copper, manganese, and zinc. 
Selenium ( $\mathrm{Se}$-_Average selenium levels in the grasses we sampled range from $0.4 \mathrm{ppm}$ to $1.2 \mathrm{ppm}$, with a combined average of $0.8 \mathrm{ppm}$ for thirty samples. Selenium in browse species appears to be considerably higher, ranging from 0.9 to $3.3 \mathrm{ppm}$ with an average of $1.9 \mathrm{ppm}$ for twenty-four samples. These figures indicate quite strongly that forage selenium levels are well above minimum requirements of $0.1 \mathrm{ppm}$, and selenium supplementation does not appear to be necessary in our sampling areas. Two samples of the 24 total samples showed selenium levels above the recommended maximum of $4.0 \mathrm{ppm}-$ since browse species are rarely the majority of the diet in this area, this should not be considered a problem. There were indications that selenium levels increase during the growing season and drop back down during plant dormancy.

Molybdenum ( $\mathrm{Mo}$ )-The functions of molybdenum are not well understood, but it has been shown to be a necessary part of certain enzymes. Minimum requirement levels have not yet been established, while maximum levels have been set at $10 \mathrm{ppm}$. There is no evidence that molybdenum deficiency occurs in cattle under practical conditions. Molybdenum levels of our samples varied a great deal from month to month, but the average ranged from $0.6 \mathrm{ppm}$ to $1.2 \mathrm{ppm}$, with an average of $0.8 \mathrm{ppm}$ for all samples. There was no significant difference between shrubs and grasses. These numbers mean that there is probably no deficiency of Mo, and our observed levels are well below reported levels of toxicity. It is well documented by research that low levels of Mo can cause a deficiency of copper; Mo levels above 2 ppm have also shown a need to increase dietary copper. Supplementation of molybdenum is not indicated; it may be better to increase copper instead.

Copper $(\mathrm{Cu})$ - It is recommended that a dietary level of 10 $\mathrm{ppm}$ is generally adequate for copper, but this is highly dependent on the levels of molybdenum and sulfur. High levels of either one, or especially both together, can increase dietary $\mathrm{Cu}$ requirements to $15 \mathrm{ppm}$ or more. The maximum recommended level is $100 \mathrm{ppm}$. Forage $\mathrm{Cu}$ levels on the Arizona Strip should be considered quite deficient. Average copper in grasses ranged from 1.3 to $2.2 \mathrm{ppm}$, with all grass samples averaging less than $2.0 \mathrm{ppm}$. Copper content of the browse species appears to be considerably higher, but the average is still less than $8 \mathrm{ppm}$. With the high levels of sulfates present in much of the drinking water in this area, the higher recommended level of dietary copper is most likely needed. Forage $\mathrm{Cu}$ levels are substantially below this, and copper supplementation is strongly indicated.

Manganese (Mn) - Manganese requirements for reproduction are higher than for growth and skeletal development, and the recommended minimum diet level is $40 \mathrm{ppm}$. Because maximum levels are set at 1,000 ppm toxicity is not likely to be a problem, although high levels of Mn can affect absorption of other minerals. Our study indicates some distinct variability among species. At higher elevations, grass Mn levels averaged $50 \mathrm{ppm}$ while shrub species averaged somewhat higher at $114 \mathrm{ppm}$. Winterfat seems to be significantly higher than other shrubs. Overall, forage from the high desert seems to contain adequate $\mathrm{Mn}$. Only two species were analyzed from the low desert - big galleta averaged $28 \mathrm{ppm}$ while the shrub white ratany averaged $15 \mathrm{ppm}$. Although much more sampling needs to be done, the tentative conclusion from our study is that $\mathrm{Mn}$ may be deficient on the lower-elevation range.

Zinc (Zn)-Minimum dietary levels for zinc have been established at $30 \mathrm{ppm}$ for beef cattle in most situations, while the maximum is set quite high at 500 ppm. High levels of calcium interfere with zinc absorption. Zinc levels in all sampled grass species averaged less than $5 \mathrm{ppm}$ - the shrubs were somewhat higher but their average was under $10 \mathrm{ppm}$. These numbers strongly indicate a need for zinc in a mineral supplement.

\section{References}

Basic Animal Nutrition and Feeding, $4^{\text {th }}$ ed.,W.G. Pond, D.C. Church, K.R. Pond

Nutrient Requirements of Beef Cattle, $7^{\text {th }}$ ed., National Research Council NRCS Field Office Technical Guide

NRCS National Range and Pasture Handbook

Cow-Calf Management Guide and Cattle Producer's Library, Cooperative Extension Service

Acknowledgments:

This study would not have been possible without the time, effort, and financing provided by several sources:

Rob Grumbles

County Extension Director

Mohave County Cooperative

Extension Service

Dr. Jim Sprinkle

Area Extension Agent, Animal Science

Gila, Yavapai, and Coconino Counties

Mohave County Grazing Advisory Board

Littlefield -Hurricane Valley

Natural Resource Conservation

District

Dr. Dick Rice

College of Agriculture

University of Arizona

Bureau of Land Management

Arizona Strip District

Fredonia Natural Resource Conservation District

Lyman Anderson

Redmond Minerals

Redmond, Utah

Steve Cassady

Range Management Specialist

Natural Resources Conservation Service

Author is with the USDA-NRCS Fredonia Field Office. 